\title{
Acute dual antiplatelet therapy for minor ischaemic stroke or transient ischaemic attack
}

\author{
(c) $(\mathbb{\Theta} \Theta$ OPEN ACCESS
}

Yongjun Wang and colleagues discuss recent evidence for using dual antiplatelet therapy to reduce recurrence of stroke or transient ischaemic attack

\author{
Yongjun Wang professor ${ }^{1234}$, S Claiborne Johnston professor ${ }^{5}$, Philip M Bath professor ${ }^{6}$, James \\ C Grotta professor ${ }^{7}$, Yuesong Pan researcher ${ }^{1234}$, Pierre Amarenco professor ${ }^{8}$, Yilong Wang \\ professor $^{1234}$, Tabassome Simon professor ${ }^{91011}$, Jong Sung Kim professor ${ }^{12}$, Jiann-Shing Jeng \\ professor $^{13}$, Liping Liu professor ${ }^{1234}$, Yi Lin associate professor ${ }^{14}$, Ka Sing Lawrence Wong \\ professor $^{15}$, David Wang professor ${ }^{1617}$, Hao Li professor ${ }^{1234}$
}

\begin{abstract}
'Department of Neurology, Beijing Tiantan Hospital, Capital Medical University, Beijing, China; ${ }^{2}$ China National Clinical Research Center for Neurological Diseases, Beijing, China; ${ }^{3}$ Center of Stroke, Beijing Institute for Brain Disorders, Beijing, China; ${ }^{4}$ Beijing Key Laboratory of Translational Medicine for Cerebrovascular Disease, Beijing, China; ${ }^{5}$ Dean's Office, Dell Medical School, University of Texas at Austin, Austin, TX, USA; ${ }^{6}$ Stroke Trials Unit, Division of Clinical Neuroscience, University of Nottingham, Nottingham, UK; ${ }^{7}$ Clinical Innovation and Research Institute, Memorial Hermann Hospital, Houston, TX, USA; ${ }^{8}$ Department of Neurology and Stroke Center, Bichat University Hospital and Paris-Diderot, Sorbonne University, Paris, France; ${ }^{9}$ Department of Clinical Pharmacology and Clinical Research Platform of East of Paris, Assistance Publique-Hôpitaux de Paris, Paris, France; ${ }^{10}$ Department of Clinical Pharmacology, Sorbonne Université, Paris, France; ${ }^{11}$ French Alliance for Cardiovascular Clinical Trials, Paris, France; ${ }^{12}$ Department of Neurology, University of Ulsan, Asan Medical Center, Seoul, South Korea; ${ }^{13}$ Department of Neurology and Stroke Center, National Taiwan University Hospital, Taipei, Taiwan; ${ }^{14}$ Department of Neurology and Institute of Neurology, First Affiliated Hospital, Fujian Medical University, Fuzhou, China; ${ }^{15}$ Division of Neurology, Department of Medicine and Therapeutics, the Chinese University of Hong Kong, Prince of Wales Hospital, Hong Kong, China; ${ }^{16}$ Illinois Neurological Institute Stroke Network, OSF Healthcare System, Peoria, IL, USA; ${ }^{17}$ Department of Neurology, University of Illinois College of Medicine at Peoria, Peoria, IL, USA
\end{abstract}

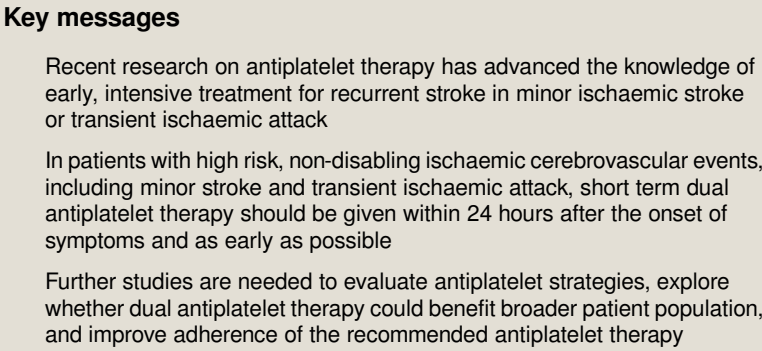

Recent research on antiplatelet therapy has advanced the knowledge of early, intensive treatment for recurrent stroke in minor ischaemic stroke or transient ischaemic attack

In patients with high risk, non-disabling ischaemic cerebrovascular events, including minor stroke and transient ischaemic attack, short term dual antiplatelet therapy should be given within 24 hours after the onset of symptoms and as early as possible

Further studies are needed to evaluate antiplatelet strategies, explore whether dual antiplatelet therapy could benefit broader patient population, and improve adherence of the recommended antiplatelet therapy

The risk of recurrent stroke and other vascular events is high in the first few weeks after index minor ischaemic stroke and high risk transient ischaemic attack (5-11.7\%). ${ }^{12}$ Dual antiplatelet therapy (DAPT), comprising clopidogrel and aspirin, is an effective strategy for reducing recurrence. ${ }^{1}$ An expert panel from the MAGIC group (http://magicproject.org/) recently produced a strong rapid recommendation in The BMJ for starting DAPT within 24 hours of symptom onset and continuing for 10-21 days in patients with minor stroke or transient ischaemic attack. ${ }^{3}$ The evidence for this came from a systematic review and meta-analysis of published clinical trials. ${ }^{4}$ Most current international guidelines, ${ }^{5-8}$ but not all, ${ }^{9}$ recommend early (within 24 hours) and short term (a duration of 21 days or 21-30 days) DAPT in patients with minor stroke or transient ischaemic attack (table 1).

Questions remain regarding choice of antiplatelet strategy, possibility of safe expansion of DAPT to a broader patient population, and adherence of patients to recommended antiplatelet therapy in clinical practice.

\section{Recent trials}

In the past five years, trials on acute antiplatelet treatment have focused on evaluating the efficacy and safety of more intensive treatment to prevent recurrent stroke after minor ischaemic stroke or high risk transient ischaemic attack. These include dual therapy versus monotherapy, ${ }^{12}$ triple versus dual antiplatelet treatment, ${ }^{10}$ and a potentially more potent agent (ticagrelor) 
compared with aspirin alone (table 2). ${ }^{11-13}$ The findings of these studies have greatly advanced the antiplatelet strategy for secondary prevention of stroke in patients with minor ischaemic stroke or transient ischaemic attack.

\section{Treatment population for DAPT}

Patients who have a minor stroke or a transient ischaemic attack are at high risk of developing thrombosis and having ischaemic brain damage that could increase their risk of bleeding. ${ }^{214}$ More intensive antiplatelet therapy could be effective and safe in these patients. The CHANCE and POINT trials compared the efficacy and safety of DAPT with clopidogrel plus aspirin against aspirin alone in patients with minor stroke (National Institutes of Health Stroke Scale (NIHSS) $\leq 3$ ) or high risk transient ischaemic attack (ABCD2 score $\geq 4$ ). The primary results from $\mathrm{CHANCE}^{1}$ and secondary analysis from POINT ${ }^{15}$ show that up to 21 days of dual antiplatelet therapy were both effective and safe (table 2), indicating that patients with minor stroke or high risk transient ischaemic attack are suitable for dual antiplatelet therapy with clopidogrel plus aspirin.

\section{Time window of starting antiplatelet therapy}

Approximately $75-80 \%$ of recurrent strokes occur in the first two weeks after onset of the index stroke or transient ischaemic attack. ${ }^{12}$ Almost all guidelines recommend that antiplatelet therapy be given as soon as possible after the diagnosis of an ischaemic event. Five of the recent trials included patients that started treatment within 24 hours (table 2). ${ }^{1211-13}$ Exploratory analysis of the TARDIS trial showed that intensive triple antiplatelet therapy could significantly reduce recurrence after mild stroke or transient ischaemic attack, or minor stroke alone, if started within 24 hours, but not if started after 24 hours (PM Bath, personal communication). This further supports the consensus that antiplatelet therapy should be given as soon as possible within 24 hours.

\section{Duration of dual antiplatelet therapy}

Risk of bleeding is the main harm of intensive dual or triple antiplatelet therapy. The CHANCE and POINT trials showed similar efficacy of DAPT with up to $\sim 30 \%$ reduction of recurrent stroke (table 2), but the POINT trial also showed a 2.3-fold increase in the risk of major haemorrhage in the DAPT group compared with aspirin alone $(\mathrm{P}=0.02)$, whereas the $\mathrm{CHANCE}$ trial did not $(\mathrm{P}=0.73) .{ }^{12}$ This discrepancy is not completely understood, but a longer duration of DAPT (90 days in the POINT trial versus 21 days in the CHANCE trial) may be the explanation. ${ }^{16}$ A secondary time course analysis of the POINT trial provided further supportive evidence for the recent rapid recommendation. ${ }^{315}$ But more systematic studies are needed to determine how to choose the duration of DAPT more precisely - between 10 and 21 days in clinical practice.

\section{Future research}

Although DAPT with clopidogrel and aspirin is an effective strategy for secondary stroke prevention, some patients fail to respond. DAPT is not effective in patients with lacunar strokes, ${ }^{17}$ but is potent in patients with multiple acute infarctions or ipsilateral atherosclerotic stenosis. ${ }^{18} 19$ Further studies are needed to thoroughly examine the effects of antiplatelet treatment on minor stroke or transient ischaemic attack with different causes and to identify those who will respond well.

Pharmacogenetics may also play an important role. A few genetic polymorphisms have been identified that might influence the metabolism of clopidogrel, which is a pro-drug that requires biotransformation to become an active metabolite and exert its effect. ${ }^{20}$ Carriers of the CYP2C19 loss of function alleles are less likely to benefit from clopidogrel. ${ }^{20}$ Although not recommended in current clinical practice, genetic testing may be considered to personalise antiplatelet therapy, especially in Asian populations, which have high prevalence of the CYP2C19 loss of function allele. Escalation of clopidogrel dosages or considering new antiplatelet agents (such as ticagrelor) could be alternatives for those carriers with CYP2C19 loss of function alleles. The efficacy, feasibility, and cost effectiveness of treatment for patients with minor stroke or transient ischaemic attack based on genetic testing requires further evaluation through randomised controlled trials.

The CHANCE trial and secondary data of POINT have shown that short term usage of dual antiplatelet therapy further reduced up to $\sim 30 \%$ of recurrent stroke without increased major bleeding compared with aspirin alone. Clinicians and researchers are eager to know whether dual antiplatelet therapy can benefit a broader population of patients who are at high risk of new stroke. The SOCRATES trial implied that the patient population at slightly more severe risk (NIHSS $\leq 5$ ) also benefited from ticagrelor compared with aspirin in reducing recurrent stroke as the secondary efficacy outcome (table 2). ${ }^{11}$ A recent meta-analysis indicated that DAPT was associated with reduced stroke recurrence among patients with acute non-cardioembolic ischaemic stroke or TIA when started within three days of ictus. ${ }^{21}$ DAPT might also be effective with acceptable safety in broader patient populations, such as those with more severe stroke (NIHSS 4-5) or in an expanded time window (within 72 hours of symptom onset). These matters need further evaluation in randomised controlled trials.

Whether a treatment is effective will eventually be influenced by patients' adherence. Although short term DAPT was shown to be safe in patients with minor stroke or high risk transient ischaemic attack, concerns still exist for bleeding risk in clinical practice. Secondary analysis of the CHANCE trial showed that DAPT may increase the risk of non-intracranial haemorrhage in patients with minor strokes. ${ }^{22}$ Mild bleeding, such as skin bruises and gum bleeding, could influence physicians' decisions and patients' adherence to antiplatelet therapy. Further research is needed to improve adherence.

In summary, DAPT should be started as soon as possible within 24 hours of minor ischaemic stroke or high risk transient ischaemic attack and should be continued up to 21 days. The 21 st day is the possible trade-off point to balance treatment effect and bleeding risk. Further studies are needed to evaluate novel and more precise antiplatelet therapy after minor ischaemic stroke and transient ischaemic attack.

Contributors and sources: YJW, SCJ, PMB, JCG, PA, YLW, JSK, JSJ, LPL, YL, $\mathrm{KSL}$, and DW are experts in clinical research on stroke and transient ischaemic attack. TS is an expert in clinical pharmacology and pharmacogenetics in cardiovascular disease. YSP and $\mathrm{HL}$ have expertise in clinical research methodology and clinical research on stroke. This article arose from The BMSS roundtable discussion on antiplatelet therapy in ischaemic stroke and transient ischaemic attack on 7 December 2018. YJW is the guarantor.

Competing interests: We have read and understood BMJ policy on declaration of interests and declare that the study was supported by grants from the Ministry of Science and Technology of the People's Republic of China (2016YFC0901001, 2016YFC0901002, 2017YFC1310901, 2018YFC1311700 and 2018YFC1311706), and grants from Beijing Municipal Commission of Health and Family Planning (No 2016-1-2041, SML20150502). 
1 Wang $Y$, Wang $Y$, Zhao $X$, etal. CHANCE Investigators. Clopidogrel with aspirin in acute minor stroke or transient ischemic attack. N Engl J Med 2013:369:11-9.

10.1056/NEJMoa1215340 23803136

2 Johnston SC, Easton JD, Farrant M, etal. Clinical Research Collaboration, Neurologica Emergencies Treatment Trials Network, and the POINT Investigators. Clopidogrel and Aspirin in Acute Ischemic Stroke and High-Risk TIA. N Engl J Med 2018;379:215-25. 10.1056/NEJMoa1800410 29766750

3 Prasad K, Siemieniuk R, Hao Q, etal . Dual antiplatelet therapy with aspirin and clopidogrel for acute high risk transient ischaemic attack and minor ischaemic stroke: a clinical practice guideline. BMJ 2018;363:k5130. 10.1136/bmj.k5130 30563885

4 Hao Q, Tampi M, O'Donnell M, Foroutan F, Siemieniuk RA, Guyatt G. Clopidogrel plus aspirin versus aspirin alone for acute minor ischaemic stroke or high risk transient ischaemic attack: systematic review and meta-analysis. BMJ 2018;363:k5108. 10.1136/bmj.k5108 30563866

5 Powers WJ, Rabinstein AA, Ackerson T, etal. American Heart Association Stroke Council. 2018 Guidelines for the early management of patients with acute ischemic stroke: a guideline for healthcare professionals from the American Heart Association/American Stroke Association. Stroke 2018;49:e46-110. 10.1161/STR.000000000000015829367334

6 Boulanger JM, Lindsay MP, Gubitz G, etal . Canadian stroke best practice recommendations for acute stroke management: prehospital, emergency department, and acute inpatient stroke care, 6th edition, update 2018. Int J Stroke 2018;13:949-84. $10.1177 / 174749301878661630021503$

7 Stroke Foundation. Clinical guidelines for stroke management 2017. Melbourne Australia. https://informme.org.au/en/Guidelines/Clinical-Guidelines-for-Stroke-Management-2017.

8 Wang Y, Liu M, Pu C. 2014 Chinese guidelines for secondary prevention of ischemic stroke and transient ischemic attack. Int J Stroke 2017;12:302-20. 10.1177/1747493017694391 28381199

9 Royal College of Physicians. National clinical guideline for stroke Prepared by the Intercollegiate Stroke Working Party. 5th ed. 2016.

10 Bath PM, Woodhouse LJ, Appleton JP, etal. TARDIS Investigators. Antiplatelet therapy with aspirin, clopidogrel, and dipyridamole versus clopidogrel alone or aspirin and dipyridamole in patients with acute cerebral ischaemia (TARDIS): a randomised, open-label, phase 3 superiority trial. Lancet 2018;391:850-9. 10.1016/S0140-6736(17)32849-0 29274727

11 Johnston SC, Amarenco P, Albers GW, etal. SOCRATES Steering Committee and Investigators. Ticagrelor versus Aspirin in Acute Stroke or Transient Ischemic Attack. N Engl J Med 2016;375:35-43. 10.1056/NEJMoa1603060 27160892

12 Wang $Y$, Wang $Y$. Ticagrelor with aspirin on platelet reactivity in acute non-disabling cerebrovascular events (PRINCE) trial. International Stroke Conference 2018, Los Angeles, 2018
13 AstraZeneca. Acute stroke or transient ischaemic attack treated with ticagrelor and asa for prevention of stroke and death (THALES). https://clinicaltrials.gov/ct2/show/ NCT03354429

14 Benavente OR, White CL, Pearce L, etal. SPS3 Investigators. The secondary prevention of small subcortical strokes (SPS3) study. Int J Stroke 2011;6:164-75. 10.1111/j.1747-4949.2010.00573.x 21371282

15 Elm JJ, Farrant M, Barsan W, et al. Time course of risk versus benefit of clopidogrel and aspirin in acute ischemic stroke and high-risk TIA: a secondary analysis of the POINT trial. World Stroke Congress 2018, Montreal, 2018.

16 Grotta JC. Antiplatelet Therapy after Ischemic Stroke or TIA. N Engl J Med 2018;379:291-2. 10.1056/NEJMe1806043 29766754

17 Benavente OR, Hart RG, McClure LA, Szychowski JM, Coffey CS, Pearce LASPS3 Investigators. Effects of clopidogrel added to aspirin in patients with recent lacunar stroke. N Engl J Med 2012;367:817-25. 10.1056/NEJMoa1204133 22931315

18 Jing J, Meng X, Zhao X, etal . Dual antiplatelet therapy in transient ischemic attack and minor stroke with different infarction patterns: subgroup analysis of the CHANCE randomized clinical trial. JAMA Neurol 2018;75:711-9. 10.1001/jamaneurol.2018.0247 29582084

19 Amarenco P, Albers GW, Denison H, etal. SOCRATES Steering Committee and Investigators. Efficacy and safety of ticagrelor versus aspirin in acute stroke or transient ischaemic attack of atherosclerotic origin: a subgroup analysis of SOCRATES, a randomised, double-blind, controlled trial. Lancet Neurol 2017;16:301-10. 10.1016/S1474-4422(17)30038-8 28238711

20 Pan Y, Chen W, Xu Y, etal . Genetic polymorphisms and clopidogrel efficacy for acute ischemic stroke or transient ischemic attack: a systematic review and meta-analysis. Circulation 2017;135:21-33. 10.1161/CIRCULATIONAHA.116.024913 27806998

21 Yang $Y$, Zhou M, Zhong X, etal . Dual versus mono antiplatelet therapy for acute non-cardioembolic ischaemic stroke or transient ischaemic attack: a systematic review and meta-analysis. Stroke Vasc Neurol 2018;3:107-16 10.1136/svn-2018-000168 30022798

22 Wang D, Gui L, Dong Y, etal . Dual antiplatelet therapy may increase the risk of non-intracranial haemorrhage in patients with minor strokes: a subgroup analysis of the CHANCE trial. Stroke Vasc Neurol 2016;1:29-36. 10.1136/svn-2016-000008 28959461

Published by the BMJ Publishing Group Limited. For permission to use (where not already granted under a licence) please go to http://group.bmj.com/group/rights-licensing/ permissionsThis is an Open Access article distributed in accordance with the Creative Commons Attribution Non Commercial (CC BY-NC 4.0) license, which permits others to distribute, remix, adapt, build upon this work non-commercially, and license their derivative works on different terms, provided the original work is properly cited and the use is non-commercial. See: http://creativecommons.org/licenses/by-nc/4.0/. 


\section{Tables}

\section{Table 1| Current recommendations on antiplatelet therapy for patients with minor stroke or TIA}

\begin{tabular}{|c|c|c|}
\hline Guideline & Antiplatelet to be used & Recommendations \\
\hline AHA/ASA, $2018^{5}$ & Aspirin plus clopidogrel & $\begin{array}{l}\text { In patients presenting with minor stroke, treatment for } 21 \text { days with dual antiplatelet therapy } \\
\text { (aspirin and clopidogrel) begun within } 24 \text { hours can be beneficial for early secondary stroke } \\
\text { prevention for a period of up to } 90 \text { days from symptom onset. (Class lla recommendation, } \\
\text { evidence level B, based on randomised data) }\end{array}$ \\
\hline $\begin{array}{l}\text { Canadian Stroke Best Practice } \\
\text { Guideline, } 2018^{6}\end{array}$ & Aspirin plus clopidogrel & $\begin{array}{l}\text { In very high risk TIA patients (ABCD2 score } \geq 4 \text { ) or minor stroke (NIHSS } 0-3 \text { ), a combination } \\
\text { of clopidogrel and aspirin should be given for } 21-30 \text { days followed by antiplatelet monotherapy } \\
\text { (such as aspirin or clopidogrel alone). (Evidence level A) }\end{array}$ \\
\hline \multirow[t]{2}{*}{$\begin{array}{l}\text { Australian Clinical Guidelines for } \\
\text { Stroke Management, } 2017^{7}\end{array}$} & \multirow[t]{2}{*}{ Aspirin plus clopidogrel } & $\begin{array}{l}\text { For high risk patients with minor ischaemic stroke or TIA, aspirin plus clopidogrel may be used } \\
\text { in the short term (first three weeks) to prevent stroke recurrence. }\end{array}$ \\
\hline & & $\begin{array}{l}\text { The combination of aspirin plus clopidogrel should not be used for the long term secondary } \\
\text { prevention of cerebrovascular disease in people who do not have acute coronary disease or } \\
\text { recent coronary stent }\end{array}$ \\
\hline \multirow[t]{2}{*}{$\begin{array}{l}\text { Royal college of Physicians } \\
\text { guideline } 2016^{9}\end{array}$} & \multirow[t]{2}{*}{ Clopidogrel } & $\begin{array}{l}\text { Patients with non-disabling stroke or TIA should receive clopidogrel } 300 \mathrm{mg} \text { loading dose } \\
\text { followed by } 75 \mathrm{mg} \text { daily. }\end{array}$ \\
\hline & & $\begin{array}{l}\text { The combination of aspirin and clopidogrel is not recommended unless there is another } \\
\text { indication-eg, acute coronary syndrome, recent coronary stent }\end{array}$ \\
\hline \multirow[t]{3}{*}{ Chinese Guidelines $2014^{8}$} & Aspirin & \multirow{3}{*}{$\begin{array}{l}\text { Using a combination of aspirin and clopidogrel for } 21 \text { days is recommended to patients with } \\
\text { minor stroke (NIHSS } 0-3 \text { ) or high risk TIA (ABCD } 24 \text { ) within } 24 \mathrm{~h} \text { of onset (Grade I } \\
\text { recommendation, class-A evidence). After } 21 \text { days, either aspirin or clopidogrel can be continued } \\
\text { for long term use (Grade I recommendation, class-A evidence) }\end{array}$} \\
\hline & Clopidogrel & \\
\hline & Aspirin plus clopidogrel & \\
\hline \multirow[t]{2}{*}{ BMJ Rapid Recommendation ${ }^{3}$} & \multirow[t]{2}{*}{ Aspirin plus clopidogrel } & $\begin{array}{l}\text { In patients with high risk TIA and minor ischaemic stroke, we recommend starting dual } \\
\text { antiplatelet therapy using aspirin and clopidogrel within } 24 \text { hours of the index event (strong } \\
\text { recommendation). }\end{array}$ \\
\hline & & $\begin{array}{l}\text { In patients with high risk TIA and minor ischaemic stroke, we recommend giving dual antiplatelet } \\
\text { therapy for } 10-21 \text { days after the index event rather than continuing for longer than } 21 \text { days } \\
\text { (strong recommendation) }\end{array}$ \\
\hline
\end{tabular}




\begin{tabular}{|c|c|c|c|c|c|c|c|}
\hline & CHANCE $^{1}$ & POINT $^{2}$ & TARDIS $^{10}$ & SOCRATES ${ }^{11}$ & & PRINCE $^{12}$ & THALES $^{13}$ \\
\hline Published year & 2013 & 2018 & 2018 & 2016 & & Recently completed & Ongoing \\
\hline Study design & $\begin{array}{l}\text { Randomised, } \\
\text { double blind, } \\
\text { placebo controlled }\end{array}$ & $\begin{array}{l}\text { Randomised, } \\
\text { double blind, } \\
\text { placebo controlled }\end{array}$ & $\begin{array}{l}\text { Randomised, open } \\
\text { label, blinded endpoint }\end{array}$ & $\begin{array}{l}\text { randomised, doub } \\
\text { parallel group }\end{array}$ & able blind, & $\begin{array}{l}\text { Randomised, open label, } \\
\text { blinded endpoint }\end{array}$ & $\begin{array}{l}\text { Randomised, } \\
\text { double blind, } \\
\text { placebo } \\
\text { controlled }\end{array}$ \\
\hline Sample size & 5170 & 4881 & 3096 & 13199 & & 675 & Estimated 13000 \\
\hline \multicolumn{8}{|l|}{$\begin{array}{l}\text { Study } \\
\text { population: }\end{array}$} \\
\hline Ethnicity & $100 \%$ Asian & $\begin{array}{l}3 \% \text { Asian } \\
75 \% \text { white } \\
20.4 \% \text { black } \\
1.5 \% \text { other }\end{array}$ & $\begin{array}{l}2 \% \text { Asian } \\
94.9 \% \text { white } \\
2.0 \% \text { black } \\
1.1 \% \text { other }\end{array}$ & \multicolumn{2}{|l|}{$\begin{array}{l}29.6 \% \text { Asian } \\
66.6 \% \text { white } \\
1.8 \% \text { black } \\
2 \% \text { other }\end{array}$} & $100 \%$ Asian & Multiethnic \\
\hline Patients & $\begin{array}{l}\text { TIA*: } 27.9 \% \\
\text { Minor strokeł: } \\
72.1 \%\end{array}$ & $\begin{array}{l}\text { TIA*: } 43.2 \% \\
\text { Minor strokeł: } \\
56.8 \%\end{array}$ & $\begin{array}{l}\text { TIA* or crescendo TIA: } \\
27 \% \\
\text { Ischaemic stroke: } 72 \%\end{array}$ & \multicolumn{2}{|c|}{ Minor stroke (NIHSS $\leq 5$ ): $73.2 \%$} & $\begin{array}{l}\text { TIA*: 16.4\%; } \\
\text { Minor strokeł: 83.6\% }\end{array}$ & $\begin{array}{l}\text { High risk TIA†, } \\
\text { ipsilateral large } \\
\text { vessel stenosis } \\
\geq 50 \% \text {, or minor } \\
\text { stroke (NIHSS } \\
\leq 5 \text { ) }\end{array}$ \\
\hline $\begin{array}{l}\text { Time from onset } \\
\text { to } \\
\text { randomisation }\end{array}$ & $\leq 24 \mathrm{~h}$ & $\leq 12 \mathrm{~h}$ & $\leq 48 \mathrm{~h}$ & \multicolumn{2}{|l|}{$\leq 24 \mathrm{~h}$} & $\leq 24 \mathrm{~h}$ & $\leq 24 \mathrm{~h}$ \\
\hline \multicolumn{8}{|l|}{ Interventions: } \\
\hline Clopidogrel & $\begin{array}{l}\text { Day 1: } 300 \mathrm{mg} \\
\text { Days 2-90: } 75 \mathrm{mg}\end{array}$ & $\begin{array}{l}\text { Day 1: } 600 \mathrm{mg} \\
\text { Days 2-90: } 75 \mathrm{mg}\end{array}$ & $\begin{array}{l}\text { Day 1: } 300 \mathrm{mg} \\
\text { Days 2-30: } 75 \mathrm{mg}\end{array}$ & & & & \\
\hline Aspirin & $\begin{array}{l}\text { Day 1: } 75-300 \mathrm{mg} \\
\text { Days 2-21: } 75 \mathrm{mg}\end{array}$ & $\begin{array}{l}\text { Days 1-90: 50-325 } \\
\mathrm{mg}\end{array}$ & $\begin{array}{l}\text { Day 1: } 300 \mathrm{mg} \\
\text { Days 2-30: } 75 \mathrm{mg}\end{array}$ & & & Days 1-21: $100 \mathrm{mg}$ & $\begin{array}{l}\text { Day 1: } 300-325 \\
\text { mg } \\
\text { Days 2-30: } \\
75-100 \mathrm{mg}\end{array}$ \\
\hline Dipyridamol & & & $\begin{array}{l}\text { Days } 1-30 \text { : either } 200 \\
\mathrm{mg} \text { twice daily or } 150 \\
\mathrm{mg} \text { three times a day }\end{array}$ & & & & \\
\hline Ticagrelor & & & & $\begin{array}{l}\text { Day 1: } 180 \mathrm{mg} \\
\text { Days 2-90: } 180 \mathrm{~m}\end{array}$ & & Day 1-90: $180 \mathrm{mg}$ & $\begin{array}{l}\text { Day 1-30: } 180 \\
\text { mg }\end{array}$ \\
\hline Controls: & $\begin{array}{l}\text { Aspirin: } \\
\text { Day 1: 75-300 mg } \\
\text { Days 2-21: } 75 \mathrm{mg}\end{array}$ & $\begin{array}{l}\text { Aspirin: } \\
\text { Days 1-90: 50-325 } \\
\text { mg }\end{array}$ & $\begin{array}{l}\text { Guideline antiplatelet } \\
\text { therapy (aspirin + } \\
\text { dipyridamol, or } \\
\text { clopidogrel alone) }\end{array}$ & $\begin{array}{l}\text { Aspirin: } \\
\text { Day 1: } 300 \mathrm{mg} \\
\text { Days 2-90: } 100 \mathrm{~m}\end{array}$ & & $\begin{array}{l}\text { Clopidogrel: } \\
\text { Day 1: } 300 \mathrm{mg} \\
\text { Days 2-90: } 75 \mathrm{mg} \\
\text { Aspirin: } \\
\text { Days 1-21: } 100 \mathrm{mg} / \text { day; }\end{array}$ & $\begin{array}{l}\text { Aspirin: } \\
\text { Day 1: 300-325 } \\
\text { mg } \\
\text { Days 2-30: } \\
\text { 75-100 mg }\end{array}$ \\
\hline $\begin{array}{l}\text { Time of } \\
\text { outcome }\end{array}$ & Day 90 & Day 90 & Day 90 & Day 90 & & Day 90 & Day 30 \\
\hline $\begin{array}{l}\text { Primary efficacy } \\
\text { outcome } \\
\text { (intervention } v \\
\text { control) }\end{array}$ & $\begin{array}{l}\text { Stroke: } \\
8.2 \% \vee 11.7 \% \\
\text { HR: } 0.68(0.57 \text { to } \\
0.81), \mathrm{P}<0.001\end{array}$ & $\begin{array}{l}\text { Stroke }+\mathrm{Ml}+\mathrm{CV} \\
\text { death: } \\
5 \% v 6.5 \% \\
\text { HR: } 0.75(0.59 \text { to } \\
0.95), \mathrm{P}=0.02\end{array}$ & $\begin{array}{l}\text { Ordinal stroke/TIA: } \\
7 \% \text { \% } 6 \% \\
\text { cOR: } 0.90(0.67 \text { to } \\
1.20), P=0.47\end{array}$ & $\begin{array}{l}\text { Stroke }+\mathrm{Ml}+\text { dea } \\
6.7 \% \vee 7.5 \% \text {; } \\
\text { HR: } 0.89(0.78 \text { to }\end{array}$ & $\begin{array}{l}\text { oth: } \\
\text { 1.01), } P=0.07\end{array}$ & $\begin{array}{l}\text { High platelet reactivity: } \\
12.5 \% \text { v } 29.7 \% \\
\text { OR:0.34 ( } 0.22 \text { to } 0.52) \\
\text { P<0.001 }\end{array}$ & Stroke + death \\
\hline $\begin{array}{l}\text { Secondary } \\
\text { efficacy } \\
\text { outcome }\end{array}$ & $\begin{array}{l}\text { Stroke }+\mathrm{M} \mathrm{I}+\mathrm{CV} \\
\text { death: } \\
8.4 \% \vee 11.9 \% \\
\text { HR: } 0.69 \text { (0.58 to } \\
0.82), \mathrm{P}<0.001\end{array}$ & $\begin{array}{l}\text { Stroke: } \\
4.8 \% \vee 6.4 \% \\
\text { HR: } 0.74(0.58 \text { to } \\
0.94), P=0.01\end{array}$ & $\begin{array}{l}\text { Stroke: } \\
4 \% \vee 4 \% \\
\text { HR: } 1.05 \text { ( } 0.73 \text { to } \\
1.51), P=0.79\end{array}$ & $\begin{array}{l}\text { Stroke: } \\
5.9 \% \vee 6.8 \% \\
\text { HR: } 0.86(0.75 \\
\text { to } 0.99), P=0.03\end{array}$ & $\begin{array}{l}\text { Stroke: } \\
6.3 \% \text { v } 8.8 \% \\
\text { HR: } 0.70(0.40 \text { tc }\end{array}$ & $\begin{array}{l}\text { Stroke } \\
01.22), P=0.20\end{array}$ & \\
\hline $\begin{array}{l}\text { Primary safety } \\
\text { outcome }\end{array}$ & $\begin{array}{l}\text { Moderate to severe } \\
\text { bleeding: } \\
0.4 \% \vee 0.3 \% \\
\text { HR: } 0.84(0.30 \text { to } \\
2.31), P=0.73\end{array}$ & $\begin{array}{l}\text { Major } \\
\text { haemorrhage: } \\
0.9 \% \vee 0.4 \% \\
\text { HR: } 2.32(1.10 \text { to } \\
4.87), P=0.02\end{array}$ & $\begin{array}{l}\text { Ordinal bleeding: } \\
20 \% v 9 \% \\
\text { cOR: } 2.45 \text { (2.05 to } \\
3.16), P<0.001\end{array}$ & $\begin{array}{l}\text { Major bleeding: } \\
0.5 \% \text { v } 0.6 \% \\
\text { HR: } 0.83(0.52 \\
\text { to } 1.34), \mathrm{P}=0.45\end{array}$ & $\begin{array}{l}\text { Major or minor } \\
4.8 \% \text { v } 3.5 \% \text {; } \\
\text { HR: } 1.36 \text { ( } 0.64 \text { tc }\end{array}$ & $\begin{array}{l}\text { bleeding: } \quad \text { Bleeding } \\
\text { o 2.88), } P=0.42\end{array}$ & \\
\hline
\end{tabular}

${ }^{*} A B C D 2$ score $\geq 4$. $† A B C D 2$ score $\geq 6$. $¥ N I H S S \leq 3$. MI=myocardial infarction. HR=hazard ratio. $c O R=$ common odds ratio. $T I A=$ transient ischaemic attack. $N I H S S=N a t i o n a l$ Institutes of Health Stroke Scale. 